\title{
Factors Analysis on Safety of Indoor Air Quality
}

\author{
Qing-hai Luo \\ Ze-hua Liu \\ Jun Xiong \\ Doc., Associate Prof. \\ Professor \\ Associate Prof. \\ College of Urban Construction, Nanhua University, \\ Hengyang, P.R.China \\ hunanluoqinghai@163.com
}

\begin{abstract}
Influence factors on safety of indoor air quality (IAQ) were analyzed in this paper. Some regeneration compositions resulting from potential indoor chemical reactions may be more harmful to habitants. A few building flaws may be key factors on safety of IAQ, including space dimensions, structure styles, and airproof materials. The impacts of ventilation on IAQ were tested with regard to supply air and contaminants, indoor air distribution, and maintenance of the ventilation system.
\end{abstract}

Keywords: safety of IAQ; potential chemical reactions; building flaws; ventilation system.

While outdoor environment is being attached importance to, the indoor environment may be ignored more or less. In modern society, the indoor pollutions have become serious factors affecting the mental and physical health of inhabitants. Some related investigation in the United States indicated that the degree of indoor pollution is 2-5 times worse than that of outdoor pollution, sometimes even exceed 100 times $^{[1]}$. In China, the indoor pollutions and hidden danger, resulting from building materials, indoor decoration and office devices, are becoming the important problems that our government and society pay attention to. Fortunately, more and more people are attaching importance to the safety of indoor air quality (IAQ).

\section{MAIN INDOOR AIR POLLUTIONS AND THE SOURCES}

Indoor air pollutions may be divided into four varieties according to the sources

(1) Volatile Organic Compounds (VOCs)

The indoor VOCs are mainly HCHO, Ammonia, Benzene, Toluene, Xylene and so on. Among them,
$\mathrm{HCHO}$ is the primary indoor air pollutant. The main sources are various building materials, indoor decoration and office devices. The petroleum and its combustion products may be another serious source of the Benzene, Toluene, Xylene and so on.

\section{(2) Combustion and Decomposition Products}

The products, resulting from burning fuels, cooking foods and high temperature frying foods, would contain not only some carcinogens but also $\mathrm{NO}_{\mathrm{X}}, \mathrm{CO}$ and Particulates. Some indoor sources, such as gas burner or gas stove, can make the concentrations of $\mathrm{NO}_{2}$ and $\mathrm{CO}$, which may reach 5 times of that of outdoors sometimes, and the concentration of $\mathrm{CO}$ would reach $11.45 \sim 34.35$ $\mathrm{mg} / \mathrm{m}^{3}$. The Tobacco smoking contains more than 4500 compounds; among them, 50 compounds are affirmed or dubitable carcinogens.

\section{(3) Biological Pollutants}

Indoor air usually contains Virus, Bacterium, and excreta from microorganisms, insects, animals and human's. Some of them may be nosogenetic or anaphylactic, for examples: causing some infectious diseases and erethism, producing some toxins, resulting in some acute or chronic influences. The moldy corn and hay, the guano dust, the polluted humidifier would contain allergen of some special pneumonia. Warm micro-environment is benefit to many microorganisms' growth and propagation, and ventilating or air-conditioning system may facilitate microorganisms' reproduction and diffusion.

(4) Radioactive Contaminations

Indoor radioactive contaminations is Niton primarily, the concerned investigation of EPA indicated that the death of 14000 peoples are related to Niton pollution in the United States every year ${ }^{[2]}$.A report of UNSEAR in 1982 indicated that the indoor 
and outdoor intensity of $\gamma$ radial are respectively $6 \times 10^{-8}$ Gy.h $\mathrm{h}^{-1}$ and $5 \times 10^{-8} \mathrm{~Gy} \cdot \mathrm{h}^{-1}$, and the typical indoor and outdoor intensity of Niton radiation respectively reach $20 \mathrm{~Bq} / \mathrm{m}^{3}$ and $0.1 \sim 10 \mathrm{~Bq} / \mathrm{m}^{3}$ The time while peoples are engaged in indoor activity approximately accounts for the proportion of $80 \%$ and $90 \%$ in the developed country, and peoples' exposure to indoor radiation accounts for $70 \%$ of the total exposure to radiation. While the application of industrial waste residues is becoming increasingly widespread, the content of radioactive contaminations of building materials is also increasing.

\section{INFLUENCE FACTORS ON SAFETY OF IAQ}

\subsection{Indoor Potential Chemical Reactions}

A building space can be regarded as a chemical vessel for contaminants emitting from furnishings, building materials and habitants. Contaminants also flow into with supply air and out with exhaust air simultaneously. On some environment conditions, potential chemical reactions may occur among ozone and indoor pollutants. Some regenerating compositions may be more harmful to habitants ${ }^{[3]}$.

The potential chemical reactions among indoor contaminants mainly include as follows:

(1) Reactions between $\mathrm{O}_{3}$ and $\mathrm{NO}_{\mathrm{X}}$. The reaction velocity basically depends on the $\mathrm{NO}_{\mathrm{X}}$ concentration and the indoor temperature.

$$
\begin{gathered}
\mathrm{O}_{3}+\mathrm{NO} \rightarrow \mathrm{NO}_{2}+\mathrm{O}_{2} \\
\mathrm{O}_{3}+\mathrm{NO}_{2} \rightarrow \mathrm{NO}_{3} \cdot+\mathrm{O}_{2}
\end{gathered}
$$

(2) Reactions between $\mathrm{O}_{3}$ and unsaturated hydrocarbon.

$\mathrm{R}_{1} \mathrm{R}_{2} \mathrm{C}=\mathrm{C} \mathrm{R}_{3} \mathrm{R}_{4}+\mathrm{O}_{3} \rightarrow \mathrm{R}_{1} \mathrm{R}_{2} \mathrm{C}=\mathrm{O}+\mathrm{R}_{3} \mathrm{R}_{4} \mathrm{COO} \cdot$

$\mathrm{R}_{3} \mathrm{R}_{4} \mathrm{COO} \cdot$ presents strong oxidbillity. Some regenerating compositions, such as $\mathrm{CO}_{2}, \mathrm{NO}_{2}, \mathrm{SO}_{3}$ or $\mathrm{O}_{3}$, may be produced respectively because of reactions between $\mathrm{R}_{3} \mathrm{R}_{4} \mathrm{COO} \cdot$ and $\mathrm{CO} 、 \mathrm{NO} 、 \mathrm{SO}_{2}$ or $\mathrm{O}_{2} \cdot \mathrm{R}_{3} \mathrm{R}_{4} \mathrm{COO} \cdot$ may be auto-decomposed into aldehyde, ketone, acid and analogous low-carbon substances.

(3) Photochemical reactions of $\mathrm{NO}_{\mathrm{X}}$. Such reactions are the basic preconditions of photochemical smog.

$$
\mathrm{NO}_{2}+\mathrm{h} v \quad(290 \sim 430 \mathrm{~nm}) \rightarrow \mathrm{NO}+\mathrm{O}\left({ }^{3} \mathrm{P}\right)
$$

$$
\begin{gathered}
\mathrm{O}\left({ }^{3} \mathrm{P}\right)+\mathrm{O}_{2}+\mathrm{M} \rightarrow \mathrm{O}_{3}+\mathrm{M} \\
\mathrm{O}_{3}+\mathrm{NO} \rightarrow \mathrm{NO}_{2}+\mathrm{O}_{2}
\end{gathered}
$$

(4) Photochemical reactions of aldehyde or ketone:

The photolysis of formaldehyde may present in two approaches:

$$
\begin{gathered}
\mathrm{HCHO}+\mathrm{h} v \quad(\lambda<370 \mathrm{~nm}) \rightarrow \mathrm{H}+\mathrm{HCO} ; \\
\mathrm{HCHO}+\mathrm{h} v \quad(\lambda<370 \mathrm{~nm}) \rightarrow \mathrm{H}_{2}+\mathrm{CO} ; \\
\mathrm{H}+\mathrm{O}_{2} \rightarrow \mathrm{HO}_{2} ; \\
\mathrm{HCO}+\mathrm{O}_{2} \rightarrow \mathrm{HO}_{2}+\mathrm{CO}
\end{gathered}
$$

The photolysis of high-carbon aldehydes may present as follows:

$$
\begin{aligned}
& \mathrm{CH}_{3} \mathrm{CHO}+\mathrm{h} \mathrm{v} \rightarrow \mathrm{CH}_{3}+\mathrm{HCO} ; \\
& \mathrm{CH}_{3} \mathrm{CHO}+\mathrm{h} \mathrm{v} \rightarrow \mathrm{CH}_{4}+\mathrm{CO} ; \\
& \mathrm{CH}_{3} \mathrm{CHO}+\mathrm{h} \mathrm{v} \rightarrow \mathrm{H}+\mathrm{CH}_{3} \mathrm{CO} ; \\
& \mathrm{CH}_{3} \mathrm{CHO}+\mathrm{h} v \rightarrow \mathrm{H}_{2}+\mathrm{CH}_{2} \mathrm{CO} ;
\end{aligned}
$$

The photolysis of ketones may be following:

$$
\mathrm{CH}_{3} \mathrm{C}=\mathrm{OCH}_{3}+\mathrm{h} \mathrm{v} \rightarrow \mathrm{CH}_{3}+\mathrm{CH}_{3} \mathrm{CO} ;
$$

While the photolysis of anisomerous ketones may present following two approaches:

$$
\begin{aligned}
& \mathrm{CH}_{3} \mathrm{C}=\mathrm{OC}_{2} \mathrm{H}_{5}+\mathrm{h} \mathrm{v} \rightarrow \mathrm{CH}_{3} \mathrm{CO}+\mathrm{C}_{2} \mathrm{H}_{5} ; \\
& \mathrm{CH}_{3} \mathrm{C}=\mathrm{OC}_{2} \mathrm{H}_{5}+\mathrm{h} \mathrm{v} \rightarrow \mathrm{CH}_{3}+\mathrm{C}_{2} \mathrm{H}_{5} \mathrm{CO}
\end{aligned}
$$

$\mathrm{O}_{3}$ is mainly produced by furniture, or follows into the space with supply air. It is a strongly oxidizing agent. Outdoor luminaries or indoor illuminants provide the basic conditions of photochemical reactions. Aerosols play the role of catalyzers of chemical reactions among indoor contaminants.

\subsection{Building Flaws on Safety of IAQ}

\subsubsection{Floor Height of Building}

With architecture engineering mushrooming, the net floor heights are becoming less in many Buildings in the recent decades, because developers hunt for high profit margin. Some decorations are also too flourishing and superfluous in some commercial buildings, offices and apartments. The net floor heights are usually in the range of $2.35 \sim 2.55 \mathrm{~m}$. The net indoor height makes significant influences on the IAQ, and it should be higher than $2.8 \mathrm{~m}$ for favorable ventilations. If it is lower than $2.55 \mathrm{~m}$, inhabitants may feel depressive, and might appear some SBS (sick building syndrome) for the concentration of contaminations are too high in the indoor breathing 
region. The maximum concentration of indoor contaminations lies in the region near the zero speed surface of ventilation, which is also the indoor breathing region, and its height is usually the $2 / 3$ height of net indoor height, namely $1.57 \sim 1.7 \mathrm{~m}$ or so. The lower net indoor height would aggravate the harm of indoor contaminations to inhabitants.

\subsubsection{Airproof Indoor Environment}

Many buildings install hardly any transoms, or transoms cannot be opened. Many transoms or louvers of public buildings can not play the role of ventilation due to poor management. Due to lack of supervision on the design, utilization and maintenance, public buildings can not meet the basic demand of natural ventilation, For example, hospital may be a source of virus. If various virus spread in hospital cannot be vented out, it will cause intercross or repeated infections among people.

On the other hand, air permeation of modern buildings is usually poor because of airproof material of door and windows. However, air permeation plays a significant role on safety of IAQ. For buildings with no ventilator, the air infiltration accounts for $1 / 5 \sim 1 / 3$ of the total fresh air, so air infiltration can not be ignored in buildings. From the view of energy conservation, many modern buildings have been built with large amount of airproof materials, which air permeability may be merely $1 / 10 \sim 1 / 5$ of that of common building materials, thus the air infiltration significantly decrease, and IAQ become unhealthy. of indoor contaminants has been proved an essential, practical, and cost-effective means to improve IAQ. However, some outdoor contaminants, such as $\mathrm{SO}_{2}$ 、 $\mathrm{NO}_{\mathrm{X}} 、 \mathrm{CO}$, bacteria and dust, may flow into indoor space, and return air may be another indoor contaminants source.

Fig. 1 and Fig. 2 illustrate the surveying data of air input, indoor $\mathrm{CO}_{2}$ concentrations, indoor and outdoor concentrations of respirable dusts of a complex building, which was surveyed at seven times in a day in July 2004 in Changsha. This is a building complex integrating a hotel, office rooms, council chambers and other recreation rooms.

The building face a busyness street, link other lower commercial buildings on two sides, and its back lies a parking lot. The building is $54.2 \mathrm{~m}$ high, 14 floors. During testing time, it was sunshiny, the outdoor temperature was $31.6-37.9^{\circ} \mathrm{C}$.

The fresh air system could not work efficiently due to wanting management. The fresh air fans were equipped dispersedly, and not controlled by the auto-control system. The majority of fresh air louvers were thoroughly opened when the IAQ was investigated at each time. Only impurity with diameter more than $2 \mathrm{~mm}$ can be captured by filters, so the concentrations of outdoor gaseous contaminations affected IAQ directly.

\subsection{Influence of Ventilating or Air-conditioning}

\section{System}

\subsubsection{Supply Air and Contaminants.}

Adequate outdoor air to dilute the concentration

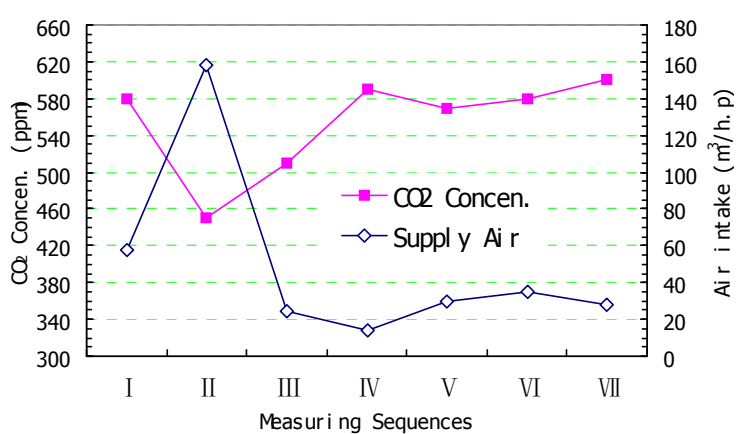

Fig. 1 Indoor $\mathrm{CO}_{2}$ concentrations varying with supply air at different measuring times 


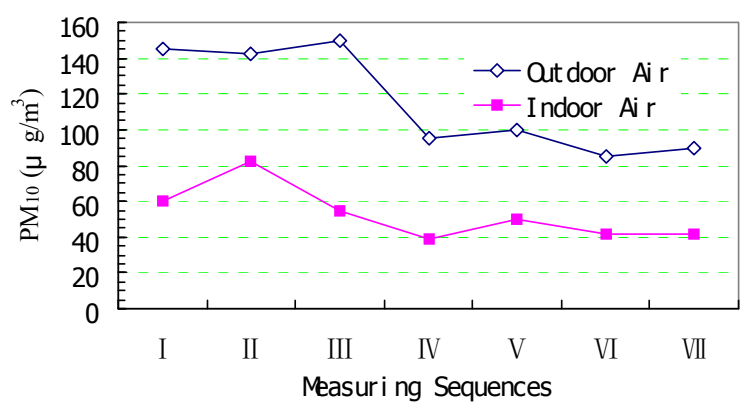

Fig. 2 Indoor and outdoor concentrations of respirable dusts at different measuring

Fig.1 shows that the indoor $\mathrm{CO}_{2}$ concentrations decreased with increasing air input. Fig.2 shows that the indoor concentration of respirable dusts increased with that of supply air. The 2nd concentration of respirable dusts was the largest, namely $82 \mu \mathrm{g} / \mathrm{m}^{3}$, because the corresponding air input was the largest, namely $157.9 \mathrm{~m}^{3} / \mathrm{h} . \mathrm{p}$, which was respectively $2.7,6.4$, $10.9,5.3,4.5,5.7$ times of others.

\subsubsection{Indoor Air Distribution}

Menzies ${ }^{[4]}$ inquired inhabitants of two healthy buildings. He discovered that the rate of inhabitant with sick building symptom was $7.12 \% \sim 14.9 \%$ for a building with fresh air input of $34 \mathrm{~m}^{3} /(\mathrm{h} \cdot \mathrm{p})$, however, $11 \% \sim 14.5 \%$ for another building with fresh air input of $85 \mathrm{~m}^{3} /(\mathrm{h} \bullet \mathrm{p})$. Which illustrated that IAQ may be not always improved by only improving ventilation rates, and proper ventilation strategies are the keys to improve IAQ.

Adequate out door ventilation air is necessary to dilute indoor air contaminants, however, the IAQ of breathing zones may be effected by heating sources, contaminant sources, airflow encumbrances and air distributions simultaneously. Improving air distribution may play double roles, namely improving IAQ and decreasing ventilation rate.

Three ventilation patterns were simulated by means of CFD method ${ }^{[5]}$. The Reynolds averaged Navier-Stokes equations and the RNG $k-\varepsilon$ turbulence model was used to predict 3D airflow pattern in a room, where barriers, pollutant sources and a centralized heating source were laid out. The indoor air velocity and temperature fields and $\mathrm{CO}_{2}$ distribution were studied numerically. Results illustrated that the displacement ventilation might bring the best IAQ and thermal comfort in the breathing zone and the higher ventilation efficiency.

\subsubsection{Maintenances of Air-conditioning System}

Dusts deposited in the duct system not only pollute fresh and indoor air, but also increase duct resistance and further decrease the air rate. On the other hand, the temperature and humidity in the air-conditioning duct system are adaptive conditions for bacteria to grow and breed. An air-conditioning system may be a contaminant source, and cleaning duct system may play double roles, namely to improve IAQ and operating efficiency. Liu et al ${ }^{[6]}$ introduced special cleaning equipments and cleaning process for HAVC system.

Table 1 presents the comparison between data of supply air, return air and bacteria in two guest rooms of a hotel before and after cleaning ducts. It indicated that bacteria decreased by $43.2 \%$, while return air increased by $16.1 \%$, and supply air increased by $36.2 \%$ simultaneously. The sampling and testing method was according to concerned criterion ${ }^{[7]}$

In addition, after the air-conditioning system of an office building was cleaned, the indoor bacteria decreased by $85.3 \%$ of maximum, and supply air increased by $55 \%$ of maximum ${ }^{[6]}$.

\section{CONCLUSIONS}

(1) Potential chemical reactions may occur among ozone and indoor pollutants on some environment conditions and some regeneration compositions may be more harmful to habitants

(2) Some building flaws may be key factors on safety of IAQ, including space dimensions, structure styles, airproof materials and son.

(3) IAQ may be not always improved by only improving ventilation rates. The impacts of 
ventilation on IAQ mainly include as follows: (i ) distribution; (iii) maintenances of ventilation system. supply air and contaminants; ( ii ) indoor air

Table 1 The comparison between ventilation data before and after cleaning ducts

\begin{tabular}{cccc}
\hline & Supply air $\left(\mathrm{m}^{3} / \mathrm{h}\right)$ & Return air $\left(\mathrm{m}^{3} / \mathrm{h}\right)$ & Bacteria $\left(/ \mathrm{m}^{3}\right)$ \\
\hline Before cleaning & 709 & 583 & 3588 \\
After cleaning & 966 & 677 & 2038 \\
\hline
\end{tabular}

\section{REFERENCES}

[1] Song Guangsheng. Handbook on Review and Detection of Indoor Environment [M]. Beijing: Mechanical Industry Press, 2003: 1-5.(In Chinese)

[2] Pan Xiaochuan. Review on Indoor Air Pollution and Its Harmfulness to Health [J]. Chin. Prev. Med., 2002,3(3):167-169 (in Chinese)

[3] Weschler CJ. , Shields C. Potential Reactions among Indoor Pollutants $[\mathrm{J}]$. Atmospheric Environment, 1997,31(21):3487-3495.

[4] Menzies D., Pasztor J. and Nunes F. 1997. Effect of a New Ventilation System on Health and Well-being of Office Workers [J]. Arch. Environ.\& Health. 52 (5): 360-367
[5] Li Xu, Weng Peifen, Sun Weimin.. Numerical Analysis of Indoor Air Distribution and Indoor Air on Three Ventilation Patterns [J]. Acta Aerodynamica Sinica, 2003, 21(3): 311-319. (In Chinese)

[6] Liu Dong, Chen Peilin, Ji Lei et al. Air Duct Cleaning-an Effective way to improve indoor air quality. Heating [J], Ventilation \& Air-conditioning, 2003,33(4):139-141 (In Chinese)

[7] Fanger PO.. Human Requirements in Future Air-conditioned Environments. In: Proceedings of Advances in Building Technology[C]. Hong Kong, Health Ministry of PRC, 2002. Sterilizing Criterion. Edition 4. P29-38. 